\title{
Dearfield Dream Project: Developing an Interdisciplinary Historical/Cultural Research Network
}

\section{Robert Brunswig ${ }^{1}$, George Junne ${ }^{2}$, Gillian Bowser ${ }^{3}$, Erin Renfrew ${ }^{4}$, Ellyn Dickmann ${ }^{5}$, Amanda Purnell ${ }^{6}$ and Mark Brown ${ }^{6,7,8, *}$}

1 Department of Anthropology, University of Northern Colorado, Candelaria Hall 2200, Campus Box 108, Greeley, CO 80639-0001, USA; E-Mail: robert.brunswig@unco.edu

2 Department of Africana Studies, University of Northern Colorado, Candelaria Hall 0140E, Campus Box 159, Greeley, CO 80639-0001, USA; E-Mail: george.junne@unco.edu

3 Natural Resource Ecology Laboratory, 1499 Campus Delivery, Colorado State University, Fort Collins, CO 80523-1499, USA; E-Mail: gillian.bowser@colostate.edu

4 Department of Biochemistry \& Molecular Biology, Colorado State University, Fort Collins, CO 80523, USA; E-Mail: erin.renfrew@rams.colostate.edu

5 College of Education and Professional Studies, College of Education and Professional Studies, University of Wisconsin at Whitewater, WH 2035, 800 W Main Street, Whitewater, WI 53190, USA; E-Mail: dickmane@uww.edu

6 Office for Undergraduate Research \& Artistry, Colorado State University, Fort Collins, CO 80523-1052, USA; E-Mail: amanda.purnel1@colostate.edu

7 Department of Ethnic Studies, Colorado State University, Fort Collins, CO 80523, USA

8 Department of Clinical Sciences, 1052 Campus Delivery, Colorado State University, Fort Collins, CO 80523-1052, USA

* Author to whom correspondence should be addressed; E-Mail: m.brown@colostate.edu; Tel.: +1-970-491-3132; Fax: +1-970-491-3483.

Received: 12 June 2013; in revised form: 6 August 2013 / Accepted: 13 August 2013 / Published: 16 August 2013

\begin{abstract}
The Dearfield Dream Project is a collaborative research initiative to conduct historical, cultural, archaeological, and environmental studies on the early 20th Century African-American colony site of Dearfield, Colorado, USA. Because the breadth and significance of the Dearfield Project requires an interdisciplinary research team, a network of research collaborators has been assembled. This research network seeks to discover, preserve, and disseminate knowledge of the site and its surrounding farmsteads' economic, social, political, and environmental history for better understanding and interpretation of its
\end{abstract}


contributions to Colorado and U.S. history. Herein, we detail progress that has been made on this important historical/cultural research project. Further, we outline the future of the Dearfield research network along with our current and anticipated subjects of inquiry.

Keywords: African-American history; culture; research network; interdisciplinary; social justice

\section{Introduction}

The Dearfield Dream Project is a collaborative research initiative to conduct archaeological, historical, and environmental studies on the early 20th Century African-American colony of Dearfield, Colorado. The breadth and significance of the Dearfield Project requires an interdisciplinary research team. Thus, a network of research collaborators has been assembled including the Black American West Museum, University of Northern Colorado, University of Colorado, Colorado State University, University of Wisconsin at Whitewater, Rocky Mountain Sustainability and Science Network, Global Women's Research Network, Weld County Government, City of Greeley, and Colorado Preservation, Inc. The Dearfield research network seeks to discover, preserve, and disseminate knowledge of the Dearfield colony and town site, its sister town of Chapelton, and the colony's outlying black-owned farmsteads' economic, social, political, and environmental history for better understanding and interpretation of their contributions to Colorado and U.S. history. The project is an outgrowth of efforts by the multi-partner Dearfield Preservation Committee, a working committee of the Black American West Museum formed in 2008 to: (1) preserve the Dearfield town site as a significant Colorado historical and heritage resource, (2) grow public knowledge, understanding, and appreciation of Dearfield colony pioneers' contributions to early 20th Century African-American efforts for social and economic self-sufficiency, and (3) communicate to present and future generations the hopes, aspirations, and trials of Dearfield community members and their descendants for social justice and equality in early 20th century America. Although the majority of this communication covers our research to date, it is important to note that this a vibrant, ongoing project. Thus, this represents the first in a series of research communications related to the Dearfield Dream Project.

\section{History of Dearfield}

In 1910, Oliver Toussaint (O.T.) Jackson purchased 320 acres east of Greeley, Weld County, Colorado, under the Desert Land Act [1-3]. Jackson was an entrepreneur and admirer of Booker T. Washington, founder of the Tuskegee Normal and Industrial Institute. Washington, styling himself as a political and social realist, advocated a middle-ground approach for achieving African-American economic self-sufficiency and social advancement in the late 19th and early 20th centuries [4,5]. His Atlanta Compromise Address to the 1895 Cotton States Exposition proposed tacit recognition of disenfranchisement and segregation if the dominant Euro-American majority would support African-American efforts in seeking economic and educational opportunities through their own efforts. 
Jackson moved to Colorado from Ohio in 1877 at the age of 24, establishing and successfully operating a catering business, cafes, a small resort, and a farm in the Denver and Boulder areas [6,7]. In 1909, he was appointed to Colorado Governor John Shafroth's staff as a messenger. In 1908, the Colorado branch of the Colored Men's National Business League, whose national president was Booker T. Washington, had formed a Denver committee to explore establishment of a "negro colony in Colorado..." as part of a national initiative [8]. The following year, League delegates met in Denver to carry “out Booker T. Washington's theory which held that every negro community in every state should have a district and a town of its own whose purpose is not to establish the entire negro community of Colorado upon this [the town's] land, but to own land upon which to let homesteads" [9]. Although the League's state chapter examined locations for their proposed community throughout Colorado, one of the most desirable sites that emerged was an area of open homestead land in northeastern Colorado, east of Greeley. O.T. Jackson, largely on his own personal initiative, formed the Negro Town Site and Land Company in 1909 and began purchasing homestead land in the Dearfield area under the Desert Act of 1877 [6,7]. Although documentary evidence is limited, it appears he had at least nominal support from the Colorado chapter of the Colored Men's National Business League. With purchase of the first "negro colony" land, Jackson formed the town of Dearfield and, assisted by the Denver-based Colored American Loan \& Realty Company (1915), tirelessly worked to recruit prospective investors, property owners and residents for an African-American agricultural colony [10-14]. In the words of historian Quintard Taylor, Dearfield had become "the last major attempt at [African-American] agricultural colonization on the high plains", following a long history of such efforts from the Antebellum era through World War I and including such well-known towns as New Philadelphia (Illinois), Nicodemus (Kansas), and Booker (Texas) [12,15-17]. Press releases announcing the colony appeared in several Colorado newspapers in 1914 [18]. In 1915, Jackson told a writer for the Western Farm Life Journal that Dearfield, including the outlying colony and town, had 27 families, 44 wood-framed houses, a planned concrete block factory, a lodge hall, restaurant, grocery store, and boarding house with 595 acres in cropland [1]. By 1918, land occupied by colony homesteaders covered more than 20 square miles and a second, smaller black town, Chapelton, had been established a few miles to the southeast. Chapelton, promoted by another colony leader, Joseph Houston, had, by 1917, become an alternative commercial, social, and education center to Dearfield, eventually hosting two churches, the colony's first and only official U.S. Post Office (1917-1922), its first formally sanctioned school (1919-1922), and a general store. The Dearfield colony may have reached its economic zenith in 1917 with marketable crops valued at $\$ 50,000,60$ residential families, and 20,000 acres of affiliated agricultural land, much of that land homesteaded under the 1862 Homestead Act and the 1877 Desert Act [1].

Awareness of Dearfield's initial success at the national level is illustrated by its being featured in two articles in the prominent The Southern Workman journal, published by the Hampton Normal and Agricultural Institute of Virginia, predecessor to the famous Tuskegee Institute the latter founded by one of Hampton's graduates, Booker T. Washington [19,20], and articles in the Western Farm Life Journal [21], and Topeka (Kansas) Plaindealer [22]. Although Washington himself never visited Dearfield, having died early in its existence (1915), his widow, son, Booker T. Washington, Jr., and his grandson, Booker T. Washington, III, visited the town on August 11, 1918 [20]. In 1920, Dearfield 
farmers' crop success prompted the area Fort Collins newspaper to carry the headline "Weld County Negroes Produce Record Crop in Dearfield Section" [23].

At its height, between 1919 and 1923, the Dearfield colony and its two black towns of Dearfield and Chapelton had a population of between 150 and 300 residents while the town of Dearfield itself was said to have contained two dozen wood-frame homes, two churches, a school, a blacksmith's shop, general store, dance hall, a cafe known as the "Lunchroom", and a filling station [1,13,24-28]. The 1920 Dearfield U.S. Census records on residents' birth places showed that the Dearfield colony's population came from diverse national and international origins, including 21 states and Mexico. Some were even recruited from other African-American towns outside Colorado, such as Nicodemus, Kansas. The dynamism of early Dearfield is illustrated by local collective road building and maintenance efforts [29], annual community fairs [30], and establishment of a school under the newly created Chapelton School District (no. 124) in 1919, the school being supported by the local Negro Agricultural Co-Op [1,31-33] and located at Chapelton. Due to higher-than-normal rainfall prior to and shortly after World War I, Dearfield residents who homesteaded or purchased farm land in the town's vicinity prospered. They raised wheat, corn, sugar beets, and vegetables until prosperity declined and then ended with increasingly severe drought of the mid-1920s and full arrival of "dust bowl" drought conditions by the late 1920s and early 1930s.

Although the collapse of Dearfield's agricultural base represents the leading factor in the decline and ultimate demise of the colony, there were certainly other contributing factors. For example, the rise of the Ku Klux Klan (KKK) and growing prejudice against ethnic minorities, particularly African Americans, made life for those minorities even more challenging. Making matters worse, in 1925, Clarence Morley, a KKK-backed candidate, was elected Colorado Governor [34] and O.T. Jackson, who had continued his employment as a governor's office messenger during previous administrations, lost his job along with the political influence it entailed at a critical time in Dearfield's history [1]. After Morley's two-year term, Jackson returned to the governor's office, but finally retired in 1933.

O.T. Jackson, Dearfield's ever-active promoter and entrepreneur, attempted to stave off its decline by advertising it as a "Valley Resort" for hunting, fishing, and weekend recreation for Denver's African-American population. A flyer distributed between 1919 and 1921 advertised its advantageous proximity to the South Platte River for hunting pheasants and deer, fishing, and access to a rich social life with weekend dances held at its Barn Pavilion dance hall, country meals at its Lunchroom, and comfortable rooms at the Dearfield Lodge. Many Denver African-Americans traveled to Dearfield for weekend entertainment by train, disembarking at the Masters Railroad depot only two miles away. However, by 1930, Dearfield had become a virtual ghost-town, its demise emphasized by omission from that year's U.S. Census, a decade after appearing in the 1920 Census. Its twin town of Chapelton appears to have largely faded away even earlier, by 1922 when its post office was decommissioned and its school relocated. Many residents moved to Denver's Five Points neighborhood and formed the core of a vibrant African-American community which exists to the present day [6,7,33].

\section{Preserving the Dearfield Legacy}

Although only a few Dearfield buildings and foundations survive, the community remains an inspirational example of African-American entrepreneurship and drive for economic self-sufficiency 
and social recognition. Efforts to preserve the heritage and lessons of Dearfield's past were an important element in creation of Denver's Black American West Museum in 1971 and subsequent research, publications, and films on the town's history [35], including its placement on the National Register of Historic Places (NRHP) in 1995. In the 1990s and early 2000s, surviving Dearfield buildings were documented, stabilized, and early site research accomplished with funding provided by the Colorado State Legislature and the Colorado State Historic Fund [25,28,36-38]. In 2005, a documentary film, Dearfield: The Road Less Traveled, was made by producer-director Donnie Betts and narrated by actor John Amos [39]. The film won several film festival awards and was nominated for a Heartland Emmy. Its airing on Public Broadcasting System radio helped raise its public recognition to regional and national levels. A new Dearfield documentary by filmmaker Charles Nuckolls will be released in 2013.

Efforts to preserve and study Dearfield's historic past were given new momentum with the formation of the Dearfield Committee in 2008 [40]. The committee, a network affiliated with the Black American West Museum, includes representatives from the museum, Weld County Government, the University of Northern Colorado, Colorado State University, the City of Greeley and its Greeley Museums, the Greeley Chamber of Commerce and its Tourism Bureau, and Colorado Preservation, Inc., all of whom have collaborated to raise funds to help the Black American West Museum pay taxes on its owned site parcels, promote newspaper articles to raise public visibility, to support long-term research and public outreach through the Dearfield Dream Project [41-43]. The committee has been successful in coordinating volunteer, private and corporate donor fundraising to help stabilize existing buildings [40], organizing annual Dearfield Day public events, and, in 2010, organizing a 100th anniversary celebration during which a permanent historical monument was dedicated at the site $[44,45]$. The interdisciplinary nature of the network allows it to advance beyond what is typical of individual-discipline based or topically limited research agendas. The Dearfield Dream Project integrates expertise and knowledge from new as well as existing sources such as: (1) archaeological evidence; (2) environmental background data; (3) primary and secondary source historical documents and photographs; (4) former resident and descendant oral history records; and (5) Geographic Information System (GIS) mapping and spatial analysis modeling. In many ways, the project mirrors similar, highly successful interdisciplinary research programs at Illinois' New Philadelphia site and the National Historic Site of Nicodemus in Kansas [15,16,46]. Although the project focuses on building a framework for advanced, integrated studies, it is also grounded in several specific research questions outlined below.

\section{Value of a Research Network}

Value is being added to this research initiative through the utilization of network analysis strategies and resulting outcomes. Specifically, as part of the research collaborative network, Dickmann is leading research associated with two key aspects related to network analysis. The first aspect includes tracking, through network analysis, the development and growth of the research network over time to better understand the critical contributions that are being made by each research network member and the way in which the various represented disciplines are engaging in discovery, preservation, and dissemination of knowledge related to the overall research project. The second aspect of network analysis related research is grounded in the development and use of retrospective network analysis. 
In Wasserman's and Galaskiewicz's book entitled Advances in Social Network Analysis: Research in the Social and Behavioral Sciences, they state that "Anthropologists have contributed much to the study of social networks and will in the future continue to contribute much to the study of social networks...." [47]. This anthropologically influenced methodology, social network analysis, provides grounding for the development and interpretation of graphical mapping of relationships and connections. Retrospective network analysis methodologies are being utilized to determine, historically, how the Dearfield community was founded, developed, and subsequently perished. Much of the data needed for this research component is being collected through in-depth analysis of evidence including archeological findings, photographs, diaries, correspondence, church records, oral history recordings, historical documents, social, political, and economic related documents, school records, tax records, and other emergent evidence. This data allows for the creation of network graphics that depict Dearfield's life through time. This two-pronged network analysis research strategy is already resulting in unique visual outcomes (dynamic sociograms) and perspectives for present and future generations as an aid in understanding Dearfield's contributions to Colorado and U.S. history.

One particularly unique element of the Dearfield research network is the inclusion of undergraduate students as valuable contributors to project research teams. For example, one team of undergraduates is working under the direction of the curator for the Avenir Museum of Design to properly document and preserve textile artifacts from the town of Dearfield that are maintained at the Black American West Museum in Denver. The Avenir Museum archives an extensive collection of textile artifacts and has an international reputation for being a leader in textile preservation. Examples of textile artifacts maintained at the Black American West Museum include historic articles of clothing, flags, and uniforms.

To date, preservation methods have been developed and applied by undergraduate researchers on several early-twentieth century artifacts. The goal of the preservation process is to isolate any Dearfield textile objects from adverse environmental exposure. Most textiles from the Dearfield historical site are constructed from either plant fibers such as cotton or flax or animal fibers like wool or silk. Thus, they are susceptible to degradation from other organic sources such as molds or bacteria. They are also degraded by exposure to excessive heat and reactive gases. Some dyes used in the textiles may also be degraded by UV exposure, become acidic and, thereby, introduce another adversely reactive condition. Dearfield textile artifacts are being categorized by fabric type, placed in corrugated textile storage boxes constructed of acid-free B-flute board containing a $3 \% \mathrm{CaCO}_{3}$ buffer in order to protect the items from acidic reactions. In the cases of protein-based fabric such as wool, the boxes must be further lined with $\mathrm{pH}$-neutral unbuffered tissue paper in order to prevent adverse reaction with the basic $\mathrm{CaCO}_{3}$ buffer. Boxes are then stored in a climate-controlled environment. Humidity is maintained between 25 and 45 percent in order to inhibit growth of bacteria or molds. As mentioned above, exposure to extreme heat can cause fabric decay, so temperatures are kept between $68^{\circ} \mathrm{F}$ and $72^{\circ} \mathrm{F}$. Light intensity is maintained between $5 \mathrm{fc}$ and $15 \mathrm{fc}$ with less than $10 \mu /$ lumen of ultraviolet light.

Another team of undergraduates has been tasked with mining information from an archive of recorded interviews with former Dearfield residents. In fact, students are involved in almost all aspects of the Dearfield research network ranging from participation in archaeological excavations [48] to reconstructing building plans for historic buildings at the town site. Undergraduates have even entered the process of raising funds to help restore and preserve those historic buildings. For example, in 2012, 
students from CSU and UNC hosted the first annual Dearfield Historic 5K at the town site and donated all proceeds to the Black American West Museum's Dearfield Restoration Fund. Also in 2012, UNC's Center for Engaged Research and Civic Action (CERCA) supervised two AmeriCorp undergraduate interns who assisted Dearfield Project investigators in development and implementation of a community volunteer program and worked with Black American West Museum staff to create a computerized museum collections inventory system. UNC and CSU students are directly involved in the Dearfield research process, volunteering and working for academic credit in the archaeological field program and analyzing artifacts in UNC's Archaeology Laboratory. To further engage undergraduates in the learning process associated with the network's research, funding has been requested from the National Endowment for the Humanities in an effort spearheaded by the University of Northern Colorado that would provide substantial support to undergraduate research assistants.

\section{Ongoing Research and the Future of the Dearfield Network}

Brunswig and Junne (University of Northern Colorado) and Brown (Colorado State University) are leading an initiative that will carry the Dearfield Dream Project into a new phase designed to impart a greater sense of certainty to the Dearfield legacy. Funding for the full scope of this project (outlined below) is being sought through multiple sources. Although the project focuses on building a framework for advanced, integrated studies, it is also grounded in several specific research questions: (1) What cultural, social, political, historic, and environmental factors from the national to the local scale contributed to the formation, initial success, and eventual failure of the Dearfield community? (2) Where did the colonists migrate from, what skills and types of social, political, and educational backgrounds did they possess, and how prepared were they to become successful farmers in the northeastern Colorado plains of the early 20th Century? (3) What were the connections and relationships of Dearfield and its members with other farming communities in their area and with other African-American communities in the state and elsewhere in the United States? (4) What lessons can we learn from the Dearfield experience about African-Americans and American society in general, both in the past and the present day?

The future of the Dearfield Dream Project over the next three years would consist of: (1) Four weeks of site remote sensing (geophysics) surveys using a cesium or fluxgate magnetometer for "first pass" survey coverage, followed by ground penetrating radar (GPR) and electrical resistivity (ER) surveys in locations shown by magnetometer survey to hold high potential for buried features and soil conditions more amenable to GPR and ER imaging techniques (e.g., subsurface building foundations, wells, privies, and artifact concentrations (trash scatters). Dearfield field archaeology has been underway for the past two years. University of Northern Colorado students and community volunteers conducted four weeks of surface surveys and test excavations at the Dearfield town site in the summers of 2011 and 2012, revealing detailed information on personal possessions, subsistence, and economic practices [48]. The 2011 and 2012 field programs were preceded and informed by "shovel test" sampling of selected site areas in 2002 as part of an earlier Colorado State Historic Fund grant [37], by earlier historical site surveys and publications, historical photograph analysis, and by data gained from subsurface geophysics surveys of selected site areas using cesium and fluxgate magnetometer and ground-penetrating radar [49]. The project's 2012 archaeological research was supported by a Colorado 
State Historical Fund grant. Use of similar geophysics-based techniques at other African-American historic town sites, such as the New Philadelphia site in Illinois, have been highly effective in reconstructing locations and "footprints" of destroyed or removed buildings and buried settlement features (wells, artifact middens, privies, etc.) [15]. (2) Environmental studies are being made of Dearfield and its environs. They include comprehensive review and analysis of published and gray literature, field studies of the local ecosystem, agricultural soils, surface subsurface hydrology, and historic climate reconstruction. The project's historic climate research will focuses on a detailed reconstruction of Dearfield and regional climate patterns from its inception (ca. 1910) to the modern day. Increment tree cores will be taken at the site on trees identified as planted by Dearfield colonists. Tree-ring cores will be analyzed for paleoclimate data using tree-ring analysis facilities located in the UNC Paleoenvironment Laboratory. Tree-ring data will be integrated with local and regional historic climate data to reconstruct weather patterns (temperatures, precipitation) which would have affected Dearfield's agricultural system during its occupation. Historic documentation of early 20th century cropping, crops and livestock-raising, and irrigation systems, along with reconstruction of historic climatic patterns, will allow researchers to identify factors related to the colony's short and medium term farming and stock-raising success and ultimate failure as an agricultural community. (3) Dearfield historic research uses primary and secondary documents such as legal, tax, census, church, and school records along with existing and planned new oral interview records and historic photograph analyses designed to enhance and broaden our knowledge on the colony's social and economic history. Oral history interviews done in the 1960s and 1970s by Paul Stewart, Black American West Museum founder, are being digitized and transcribed by UNC's Michener Library Archives Department under the direction of archivist Jay Trask and Africana Studies professor, Dr. George Junne. Oral history interview data provide detailed and personalized records of individuals, families, and the community as a whole, as well as insights into the town's physical organization (e.g., buildings, wells, etc.) not identifiable in currently available historical documents and photographs. Historic source data are being correlated with emerging archaeological data to construct an interdisciplinary perspective of Dearfield's development within its historical, social, political, economic, and geographic contexts. Externally, Dearfield's political, economic, and citizen connections with other African-American communities and historical agricultural colony movements in the region and country are being explored. (4) A landscape mapping and spatial analysis model of historic Dearfield within its platted town boundaries and its associated black farmsteads, from its inception (1910) to the present day, is under development utilizing 3-dimensional spatial data with Geographic Information System (GIS) software. The project's GIS software platform is ESRI's ArcGIS 10.0. Both cultural and non-cultural spatial variable data sets will be spatially mapped and statistically correlated within the Dearfield GIS project. Existing or in-development GIS project mapping layers consist of: (a) a geo-referenced, original town plat plan reified by a formal retracement land survey of the original town plat area by Alles and Associates of La Salle, Colorado, in 2009; (b) precise locations of currently intact and former, but now absent, Dearfield public, business, and residential buildings whose precise locations and dimensions are being determined through site-based historical and archaeological investigations. Locations of now absent buildings are being established with evidence from oral history accounts, property tax records, school and church records, historic photographs, historic aerial photos, ground-level historic photographs dating as early as 1914, subsurface geophysics surveys, and archaeological excavations. In summer 
2011, primary and secondary site survey datums were established for conducting Laser Total Station (EDM) surveys. The site's primary datum was Universal Transverse Mercator (UTM) georeferenced using extended logging by a sub-meter survey grade Trimble Global Positioning System (GPS) unit. All extant structures and building foundations are spatially recorded to an accuracy of $\pm 1 \mathrm{~cm}$ using a Sokkia Laser Total Station. Survey stakes associated with the 2009 town plat retracement survey were recorded with the total station, allowing precise alignment with the original town plat and associated blocks and lots; (c) as archaeological surveys and excavations continue, locations of other site features are identified and mapped into the GIS database, including wells, privies, outbuildings, and artifact (trash) scatters. 2011 and 2012 surveys and archaeological field work, coupled with analysis of historic photographs, have been successful in identifying earlier historical survey misidentifications of some building functions and locations, bringing greater precision to understanding of the Dearfield town site's settlement pattern.

Beyond the more immediate Dearfield town site, physical, archaeological and historical data on the larger colony's farms within a twenty-square mile area makes up an important GIS project layer which facilitates project researchers' reconstruction of the colony's overall cultural landscape, providing insight into historical development of its "hinterland" in relationship to both the Dearfield and Chapelton town sites. Another GIS layer involves sub-surface geophysics survey maps. Eventually, magnetometer, Ground-penetrating Radar (GPR), and electrical resistivity (ER) survey maps, are expected to cover the majority of both the Dearfield and Chapelton town sites known to have contained structures from $c a$. 1914 to the present (note: many platted Dearfield blocks and lots were never occupied). Non-cultural spatial data layers entered into the GIS project are those associated with hydrology (surface and subsurface), natural vegetation, and soil types. Locational and historical ownership and land use data on Dearfield colony farms as well as data on the smaller African-American town of Chapelton are being incorporated into the project's Dearfield GIS mapping and modeling analysis. Colorado State Historical Fund-supported field research in 2012 included reconnaissance surveys of several outlying Dearfield farmstead locations and was successful in locating physical remains of the Chapelton town site. A colony-wide GIS layer will allow project researchers to reconstruct Dearfield's overall cultural landscape, providing insight into historical development of its "hinterland". A preliminary study of the Dearfield colony's cultural landscape was recently completed as a Historic American Landscapes (HAL) study by Kevin Lyles (American Society of Landscape Architects) and project researchers Robert Brunswig and George Junne, filed with the National Park Service in 2012.

\section{Conclusions}

The interdisciplinary network of Dearfield Dream researchers seeks to discover, preserve, and disseminate knowledge of the economic, social, political, and environmental histories of African-American Dearfield and Chapelton town sites and surrounding colony farmsteads for better understanding and interpretation of their contributions to Colorado and U.S. history. Using both classic and state-of-theart research protocols, this team has rediscovered a rich and important chapter in the cultural history of the United States. These protocols along with the interdisciplinary network of researchers provide a model upon which future cultural/historical research networks can be built. 


\section{Acknowledgments}

Bowser and Brown thankfully acknowledge support from the National Science Foundation (1140182), (0956059), and (1060548). All acknowledge the rich contributions of the Black American West Museum, the Dearfield Preservation Committee, community volunteers, and faculty, staff and students at UNC and CSU, and for archaeological research support of the Colorado State Historical Fund.

\section{Conflict of Interest}

The authors declare no conflict of interest.

\section{References}

1. Peggy Ford. "Dearfield: Chronology of a Dream." Archives of the Greeley History Museum 1 (2007): 1-15.

2. Karl S. Landstrom. "Reclamation under the Desert-Land Act." Journal of Farm Economics 36 (1954): 500-08.

3. John T. Ganoe. "The Desert Land Act in Operation, 1877-1891." Agricultural History 11 (1937): 142-57.

4. Robert R. Moton. "A Life of Achievement: Booker T. Washington." The Southern Workman 46 (1917): 177-82.

5. Booker T. Washington, and William Edward Burghardt Du Bois. The Negro in the South, His Economic Progress in Relation to His Moral and Religious Development. Philadelphia: G.W. Jacobs \& Co., 1907.

6. George Junne. "Denver in the Harlem Renaissance." In Harlem Renaissance in the West: The New Negro's Western Experience. Edited by Bruce A. Glasrud, and Cary D. Wintz. New York: Routledge, 2011.

7. George Junne, Osita Ofoaju, Rhonda Corman, and Rob Reinsvold. "Dearfield, Colorado: Black Farming Success in the Jim Crow Era." In Enduring Legacies: Ethnic Histories and Cultures of Colorado. Edited by A. Aldama. Boulder: University Press of Colorado, 2011.

8. "Colorado Negro Colony." Breckenridge Bulletin, 27 June 1908.

9. "Negro Town for Colorado." Colorado Transcript, 5 August 1909, 2.

10. "Dearfield and its Opportunities." Denver Star, 11 April 1914, 1.

11. "Denver Lot Contest." Denver Star, 9 January 1915, 4.

12. Quentin Taylor. In Search of the Racial Frontier: African Americans in the American West, 15281990. New York: W.W. Norton, 1998.

13. Karen Waddell. "Dearfield... A Dream Deferred." Colorado Heritage 2 (1988): 2-12.

14. George H. Wayne. "Negro Migration and Colonization in Colorado, 1870-1930." Journal of the West 15 (1976): 102-19.

15. Anna S. Agbe-Davies. New Philadelphia Archaeology Project. Urbana-Champaign: University of Illinois, 2010.

16. J. Keith Everett, ed. Promised Land on the Solomon: Black Settlement at Nicodemus, Kansas. Denver: Department of the Interior, 1986. 
17. "Nicodemus National Historic Site: Long-Range Interpretive Plan." Harpers Ferry, National Park Servic, Department of the Interior, September 2009. Available online: http://www.nps.gov/hfc/ pdf/ip/2010-02-22-nico-finaldocument.pdf (accessed on 9 August 2013).

18. "Plans City for Colored Race." Colorado Transcript, 26 February 1914, 7.

19. William J. Harsha. "The Pluckiest Pioneers I Know." The Southern Workman 45 (1916): 161-74.

20. William J. Harsha. "Remarkable Progress at Dearfield." The Southern Workman 48 (1919): 176-86.

21. Frederick P. Johnson. "Agricultural Negro Colony in Eastern Colorado." Western Farm Life Journal (1915): 5-12.

22. David T. Miller. "Dearfield." Topeka Plaindealer 20 (1918): 2.

23. "Weld County Negroes Produce Record Crop in Dearfield Section." Fort Collins Courier, 23 November 1920, 5.

24. Karen W. Dixon. "National Register of Historic Places Nomination for Dearfield, Weld County, Colorado." Weld County: Greeley, CO. 1990.

25. Rheba Massey, Karen Waddell, and Jan Wooley. Historic Survey of the Townsite of Dearfield, Colorado. Fort Collins: Colorado Historical Society, 1985.

26. Melvin Edward Norris. Dearfield Colorado-The Evolution of a Rural Black Settlement: An Historical Geography of Black Colonization on the Great Plains. Boulder: University of Colorado, 1980.

27. Margaret Picher. "Dearfield, Colorado: A Story from the Black West." Master thesis, University of Denver, 1976.

28. Karen Waddell. Dearfield Colorado: A Survey of Homesteading and Town Development. Fort Collins: Western Public History Associates, 1994.

29. "Colorado State News." Oak Tree Times, 28 Setember 1916, 6.

30. "Notice of a Negro Exhibition and Fair." Haswell Herald, 14 September 1916, 3.

31. Eileen Carlson. A View of Orchard: Roots and All. Boulder: Johnson Printing, 1994.

32. Carol R. Shwayder. Weld County Old and New: Schools and School Districs 1861-1990. Greeley: Unicorn Ventures, 1983.

33. Ronald J. Stephens, La Wanna M. Larson, and Black American West Museum. African Americans of Denver. Chicago: Arcadia Publishing, 2008.

34. John H. Davis. "Colorado Under the Klan." Colorado Magazine 42 (1965): 93-113.

35. P. Stiff, and C. Stewart. "The Dream of Dearfield." Denver Post Empire Magazine (1969): 47-51.

36. Black American West Museum. Acquisition and Stabilization of Dearfield Buildings. Denver: Colorado State Historic Fund, 1995.

37. Brad Noisat. An Archaeological Assessment of the Dearfield Site, Weld County, Colorado. Niwot: Niwot Archaeological Consultants, 2003.

38. Steven Watada. Historic Dearfield, Colorado, Land Acquisition Study, Vol. 1; Dearfield Townsite Exterior Maintenance and Security Plan, Vol. 2. Denver: Black American West Museum, 2003.

39. Donnie I. Betts. Dearfield: The Road Less Traveled. Denver: No Credits Production, Inc, 2005.

40. Bill Jackson. "Commissioner Works to Save Dearfield History in East Weld." Greeley Tribune, 30 July 2008. http://www.greeleytribune.com/article/20080730/NEWS/967572245. 
41. Angela Alton, and Nancy Lynch. "Historical Hindsights: A Drive for Black Community thrived in Weld." Greeley Tribune, 19 February 2010. http://www.greeleytribune.com/article/20100219/ NEWS/100219606.

42. Mary Voelz Chandler. "Brothers Recall Life as Children in Dearfield." Rocky Mountain News, 4 July 2008.

43. Mary Voelz Chandler. "Dearfield Gets Second Chance at Life." Rocky Mountain News, 4 July 2009. http://m.rockymountainnews.com/news/2008/jul/04/dearfield-gets-second-chance-life/.

44. Dan England. "Former Farming Community of Dearfield Celebrates 100-Year Milestone." Greeley Tribune, 27 September 2010.

45. Tom McGhee. "Ghost Town of Dearfield Marks 100th Anniversary." The Denver Post, 27 September 2010.

46. Bahr Vermeer Haecker Architects, Ltd. Nicodemus National Historic Site: Historic Structures Report Update. Omaha: Midwest Regional Office, Department of the Interior, 2010.

47. Jeffrey C. Johnson. Anthropological Contributions to the Study of Social Networks. Thousand Oaks: SAGE Publications, 1994, 143.

48. Robert H. Brunswig. Preliminary Report on 2011 Archaeological Investigations at the Historic African-American Farm Colony Site of Dearfield, Northeastern Colorado. Greeley: University of Northern Colorado, 2011.

49. Andrew Creekmore. Dearfield Magnetometry Survey Report. Greeley: University of Northern Colorado, 2011.

(C) 2013 by the authors; licensee MDPI, Basel, Switzerland. This article is an open access article distributed under the terms and conditions of the Creative Commons Attribution license (http://creativecommons.org/licenses/by/3.0/). 